Cinémas

Revue d'études cinématographiques

Journal of Film Studies

\title{
Toronto's "Girl Workers." The Female Body and Industrial Efficiency in Her Own Fault
}

\section{Shelley Stamp Lindsey}

Volume 6, numéro 1, automne 1995

Le cinéma muet au Québec et au Canada : nouveaux regards sur une pratique culturelle

URI : https://id.erudit.org/iderudit/1000960ar

DOI : https://doi.org/10.7202/1000960ar

Aller au sommaire du numéro

Éditeur(s)

Cinémas

ISSN

1181-6945 (imprimé)

1705-6500 (numérique)

Découvrir la revue

Citer cet article

Lindsey, S. S. (1995). Toronto's "Girl Workers." The Female Body and Industrial Efficiency in Her Own Fault. Cinémas, 6(1), 81-99.

https://doi.org/10.7202/1000960ar
Résumé de l'article

Her Own Fault est un film éducatif, produit en 1921 par le Conseil provincial de la santé de l'Ontario au sein de sa division de l'hygiène industrielle. Dans sa volonté d'influencer les femmes travailleuses de Toronto, le film fait état de certains défis posés aux travailleuses d'usine au début du siècle. Cet article situe Her Own Fault en rapport à un autre discours contemporain sur le travail des femmes et leurs habitudes de loisirs. L'auteure considère aussi le traitement que le film fait des travailleuses et les façons dont il circonscrit leur comportement et leur regard. 


\title{
Toronto's " Girl Workers." The Female Body and Industrial Efficiency in Her Own Fault ${ }^{1}$
}

\section{Shelley Stamp Lindsey}

\begin{abstract}
RÉSUMÉ
Her Own Fault est un film éducatif, produit en 1921 par le Conseil provincial de la santé de l'Ontario au sein de sa division de l'hygiène industrielle. Dans sa volonté d'influencer les femmes travailleuses de Toronto, le film fait état de certains défis posés aux travailleuses d'usine au début du siècle. Cet article situe $\mathrm{Her}$ Own Fault en rapport à un autre discours contemporain sur le travail des femmes et leurs habitudes de loisirs. L'auteure considère aussi le traitement que le film fait des travailleuses et les façons dont il circonscrit leur comportement et leur regard.
\end{abstract}

\section{ABSTRACT}

Her Own Fault is an instructional film produced by Ontario's Provincial Board of Health through its Division of Industrial Hygiene in 1921. In its attempt to influence Toronto's working women, the film suggests some of the challenges posed by the female factory worker in the early part of the century. This article will situate Her Own Fault in relation to other contemporary discourse on women's work and leisure habits. The author will also consider the film's treatment of female factory workers and the ways in which this film might circumscribe her behaviour and her gaze.

Her Own Fault ${ }^{2}$ was billed as an educational title intended to promote " $[\ldots]$ personal hygiene among industrial women 
workers" ${ }^{3}$ when it was released by the Ontario Motion Picture Bureau in the fall of 1921 . Produced by the provincial Board of Health in its Division of Industrial Hygiene, ${ }^{4}$ the film was designed to encourage better eating, sleeping, and grooming habits among Toronto's growing female work force, with the ultimate aim of improving industrial output and efficiency. Specifically targeted toward women industrial workers, the film attempts to speak to its viewers within the paradigms of conventional narrative cinema presumably familiar to them. Her Own Fault " [...] is a story of a factory girl, and should, we hope, be interesting to most girl workers, "s the Division of Industrial Hygiene claimed upon the film's release. However, the film's ostensible concern for women's "health" cloaks its broader attempt to grapple with the vexing figure of the female industrial worker in the modern urban landscape. Struggling to shape and place the female body within industrial manufacturing, where it did not immediately belong, Her Own Fault suggests something of the problems posed by such a project.

The female factory labourer remained a potent symbol of modernity in the early twentieth century, for she challenged conventional norms of femininity, ideas about industrial labour, and divisions between family and industry which had kept women labouring almost exclusively at home or in the homes of others. By the time Her Own Fault was released in 1921 women were highly visible participants in the paid labour market. With half of all single women in Ontario employed outside their homes, women comprised close to one-third of Toronto's work force. Even in the province's industrial manufacturing plants, not typically associated with female labour, women held one position in every five. ${ }^{6}$ Indeed, the growing need for low-waged, unskilled factory labour after the turn-of-the-century meant that women frequently displaced men in jobs at the lower end of the industrial spectrum. ${ }^{7}$ Underpaid, adaptable and extremely mobile, young, single women formed a vital component of industrial production, however much factory work might have defied expectations about womanly conduct.

The scrutiny that female wage-earners received in Toronto media suggests something of the challenges they posed to the 
city's residents. A journalist working undercover in Toronto factories published a series of reports in the Toronto Star in 1912, offering the paper's middle-class readers a surreptitious view of the conditions young women endured at work inside the city's manufacturing plants. ${ }^{8}$ Armed with such evidence, middle-class women's reform organizations fought for legislation designed to protect women in industry. Together with newly-formed provincial agencies charged with regulating industrial sites, they demanded that factories furnish regular breaks, adequate seating, proper lighting and ventilation, separate washrooms and clean drinking water for their female work force. ${ }^{9}$ Along with many other provinces, Ontario passed minimum wage legislation for women in 1920, guaranteeing female workers wages by which they could support themselves in a large city like Toronto. ${ }^{10}$ Still, as Alice Klein and Wayne Roberts have argued, these remedies did little to challenge the parameters of conventional femininity; if anything, protective legislation reinforced the supposed incongruity of women and industrial labour by problematizing women's status there. "

While provincial regulations increasingly shaped women's lives behind factory walls, equal concern mounted about the changing living conditions that industrial occupations imposed on female employees, since factory jobs drew women to Toronto where manufacturing plants congregated. New housing arrangements were necessary for young, unmarried women who had not normally lived apart from their families, nor unaccompanied in an urban environment. Such heterodox living patterns also posed the challenge of negotiating the wage-earner's relationship to the city itself, a terrain conceived to be hostile to upstanding young women. ${ }^{12}$ Industrially-imposed structures of work and leisure put women in contact with Toronto's burgeoning commercial recreation culture. For the first time, many women had a limited, but precious, disposable income to spend on the inevitable temptations of the city's retail and entertainment culture. These were conditions over which legislation had little or no authority.

Threats to wage-earning women's "health" were thus broadly interpreted to encompass not just the hazards of factory labour itself, but the entire sphere of modern urban living. Limited 
(and quite legitimate) apprehensions about women's physical well-being in the gruelling climate of early twentieth-century industry were displaced onto the much larger question of whether or not modernity was compatible with expected feminine decorum. Against this backdrop, then, Her Own Fault suggests that "industrial hygiene" extends beyond the immediate confines of the factory setting to encompass all facets of working women's existence. Eating habits, grooming customs, living accommodations, leisure pursuits, and courtship all fall within the purview of the Board of Health's paternal gaze. In the name of greater efficiency improved work performance becomes a means of moulding the female character, and ultimately the female body, along an industrial model. If legislation protected women within the factory, here the province aims to use its suasive powers to protect and shape womanly norms outside the factory where the "perils and pleasures" of modern Toronto beckon. ${ }^{13}$

Shot on location in Toronto during the summer of 1921, the film features various sites around the city: Queen's Hall, a woman's residence on Queen's Park, High Park in the west end, and the vast Gutta, Percha and Rubber plant in Parkdale which produced all manner of rubber goods, including shoe soles the women are seen working on in the film. Many of Gutta Percha's female employees were used in scenes filmed at the plant. ${ }^{14}$ Location shooting lends authenticity to the film's portrait of urban conditions, and roots its argument in scenes presumably familiar to its intended audience of the city's working women. Yet, a tension develops between this verisimilitude and the film's schematic portrait of two female workers: Eileen, a model employee whose sensible habits make her a productive worker and ultimately place her in line for a promotion; and Mamie, a slacker whose unwholesome lifestyle lands her in the hospital with tuberculosis, unable to work. Each embodies a different attitude to the new urban, industrial environment in a structural opposition governed by the patterns of the work day. Beginning as each rises and readies for work, parallel editing contrasts the workers' activities outside the factory; later, two-shots of the women at work on the same factory bench demonstrate the impact that each worker's lifestyle has on her productivity. 
At home before leaving for work Mamie devotes considerable attention to her appearance, standing before the mirror dressing, arranging her hair, and applying make-up, all in lieu of bathing. In an exaggerated parody of working-women's fashion at the time, she dons a chiffon blouse, a plaid skirt, a flowerfestooned hat, endless strands of beads, and copious amounts of scent and face powder - an excessive and utterly impractical wardrobe for factory labour. It is almost as if she intends to disprove single-handedly contemporary commentators' fears that industrial work might jeopardize traditional womanliness. Framed with her back to the camera and visible only through her mirror reflection, Mamie appears to value surface appearances above all else. A close-up showing her adorning her face with a thick layer of powder casts this ritual as a perverse inversion of the bathing act she has forsaken: she is covering over, rather than washing off. The film suggests that Mamie's fashion sense, beyond its ill effects on personal hygiene, may actually be hazardous to her health : later she twists her ankle on three-inch

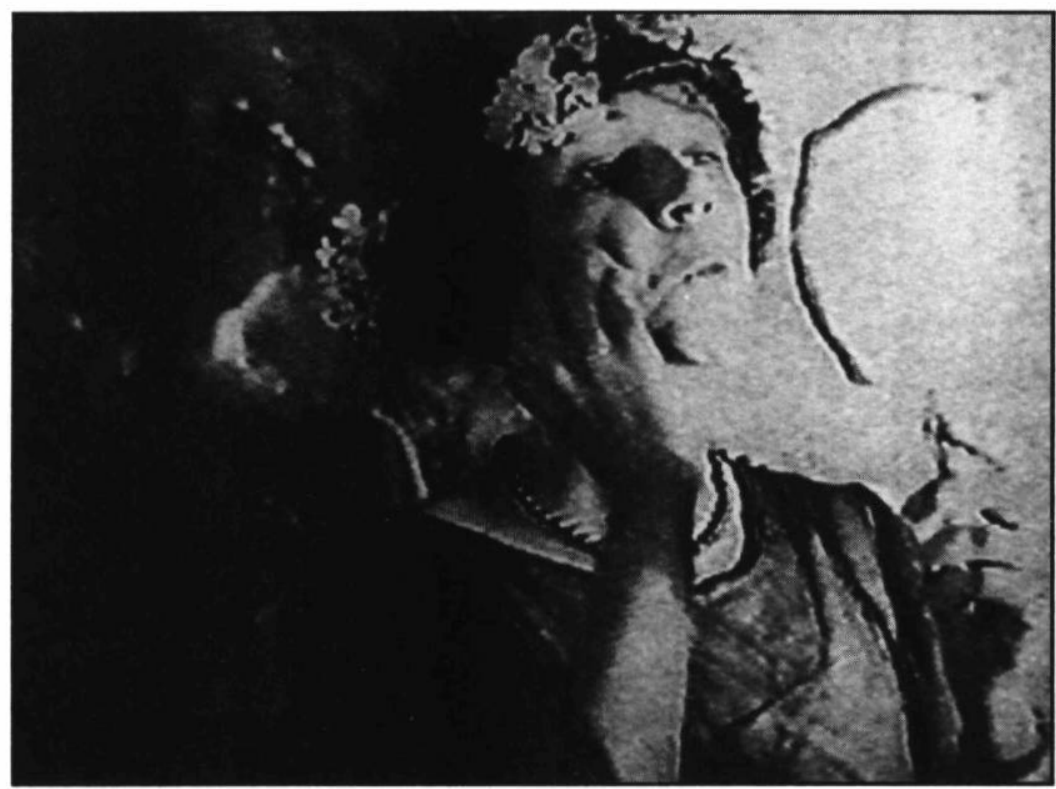

Mamie prepares for work, adorning her face with a thick layer of powder instead of bathing. 
heels in the company cafeteria, and vainly refuses to wear eye glasses to help ease the eye strain caused by hours of repetitive labour. "See me dead first," she quips.

Mamie's near-perilous devotion to style is associated here and elsewhere with the general demands of cosmopolitan life, and the particular pleasure of shopping - perhaps the greatest of all urban vices. She confesses in the opening scene to having spent her entire savings on a new hat, rather than a more serviceable lightweight suit she needs for summer weather. Being overlywarm in out-of-season clothing is little hardship, as long as she radiates an aura of stylishness. But shopping threatens more than her pocketbook when she opts to spend her lunch hour at a blouse sale where, a title warns viewers, "blouses [are] cheap in money but expensive in nervous energy," since so much jostling is required to fight one's way through the crowds. Poor Mamie even loses a lock of hair in a frenzied scuffle with another customer.

The canvas against which Mamie's elaborate visual facade is played becomes apparent after she leaves the boarding house where she lives and catches a hurried breakfast at a downtown café. Gulping down a mug of coffee and a sweet roll, she murmurs, "Wish I'd time for a real breakfast," as the film again draws attention to her imprudent habits. Bustling Toronto street life is visible through the café window as streetcars, automobiles, horse-drawn carts and pedestrians flow past in all directions. Framed by the window, the street scene appears as if on screen, in front of which Mamie sits eating her breakfast - the proximity of urban life seeming as ill-advised as the speed with which she gobbles her meagre fare. Yet, all of the mirror-front preparations of the opening scene are rendered legible here. She must don a costume, strike a pose, assume an attitude, in order to navigate the urban landscape each morning.

Among the "usual criticism" launched at Toronto's working women were complaints that they were "habitually "overdressed' and under clothed," that they "spend their money on their backs," and that they "use paint and powder instead of soap and water." This according to a monograph entitled Health Confessions of Business Women issued by the Division of 
Industrial Hygiene just two years after it released Her Own Fault. ${ }^{15}$ It suggests that the concerns expressed in the film were indeed pervasive. As Kathy Peiss has documented in the American context, outlandish dress became a mode of expression for working-class women in the urban milieu. ${ }^{16}$ "Putting on style" enabled them to escape their mechanized work lives and to experiment with class mobility, using the body as instrument of display. "At night the girls all fix themselves up, the paint and powder is put on thick, and they pretend not to be working girls, " ${ }^{17}$ one Toronto observer remarked of workers in a garment factory.

If Mamie exploits all of the vices of city dwelling - voguish fashions, boarding house living, shopping, restaurant meals, and as we see later, dance halls - her virtuous counterpart Eileen transposes a traditional, pre-industrial lifestyle onto her experiences working in a downtown factory. In scenes directly juxtaposed with Mamie's preparations for work, Eileen is associated with nature, cleanliness and lack of artifice. A delicate breeze

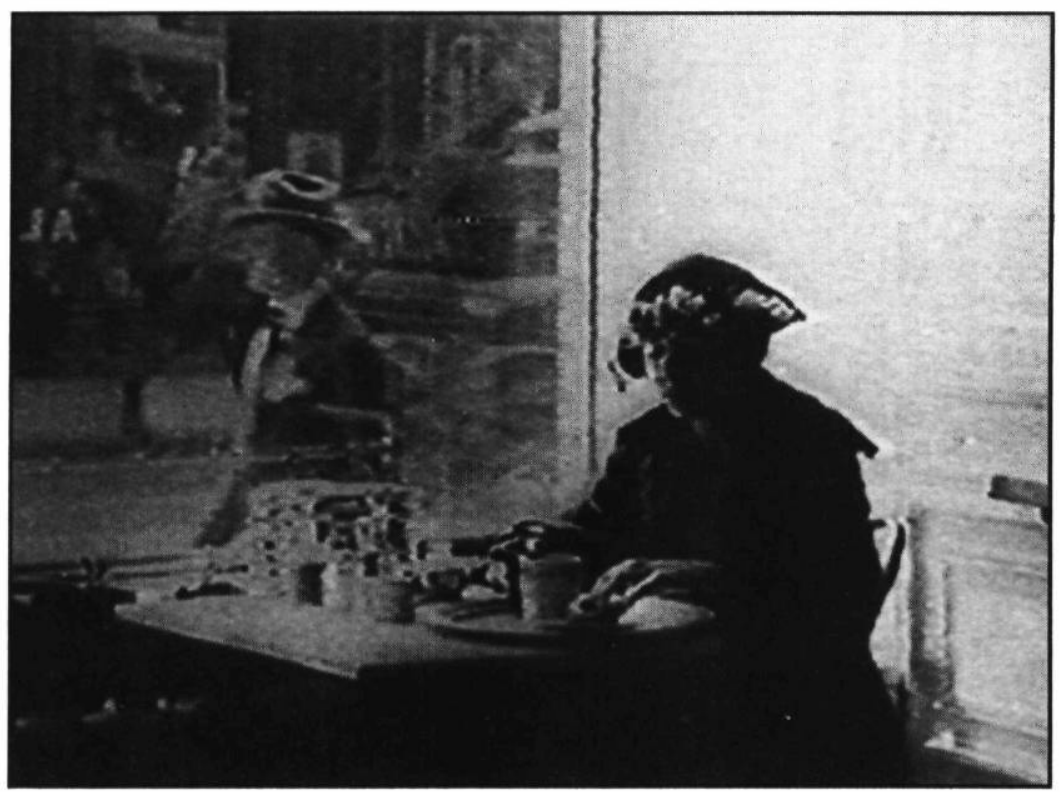

Mamie catches a hurried breakfast at a Toronto café against the backdrop of bustling urban street life. 
blows in through her bedroom window when she awakens and trees are visible outside, where Mamie's visual horizons are defined only by concrete. Upon rising Eileen immediately draws a bath and brushes her teeth - necessities forsaken by Mamie in the shameless pursuit of fashion. Eileen's clean, "natural" beauty and her eminently sensible, man-tailored vest and jacket offset Mamie's exaggerated costuming. Eileen needs just a moment in front of the mirror simply to ensure that her hat sits correctly. Even though living away from her family, she enjoys a semblance of domesticity in the home where she boards with an elderly woman and a young mother with three small children, a living arrangement much closer to rural family life than the cramped boarding house where Mamie lives watched over by a gossipy matron.

These contrasts are later underscored during the workers' morning rest period when Eileen participates in factorysupervised calisthenics outdoors, while Mamie remains inside flipping though the newspaper looking for clothing ads and reapplying her face powder. Coughing and wiping her nose, Mamie appears to be manufacturing the rosy-cheeked appearance of health Eileen achieves naturally through exertion. Concealing ill health or lack of cleanliness by "the painting out of nature's danger signals" was, according to the Division of Industrial Hygiene's monograph, "astoundingly foolhardy." ${ }^{18}$ In doing so Mamie adopts a masquerade of femininity, a false womanhood demanded by Toronto street life, but utterly at odds with the truly wholesome femininity Eileen embraces, a posture much better suited to industrial production.

It is not simply Eileen who is associated with traditional womanliness; the factory itself is presented as a space where older domestic traditions survive. Mamie's noontime shopping expedition is contrasted to the other women's activities in the sunfilled factory lounge where Eileen and two co-workers sit in rocking chairs doing needlework and flipping through magazines, talking and laughing in a pointedly domestic setting. Browsing through magazines, these women navigate modernity at one remove, surveying fashion pictorials rather than actually going to the shops. As viewed here, the factory offers women a 
surrogate family where they might pursue healthful exercise and quiet, conventional passtimes. Set against the brutal competitiveness of Mamie's blouse sale, industry seems to offer a powerful lesson in female solidarity. Here the factory is cast as a "refuge" from modernity, rather than one of its most notable landmarks.

After hours Mamie again ventures into the city, visiting a dance hall where, a title explains, "too tired for real exercise, too nervous to rest, [she] seeks excitement." Inside the club's cramped, shadowy cavern male and female couples gyrate together almost madly, neither talking nor interacting. Shots which frame the couples' legs and feet dancing in wild abandon mimic the earlier framing of the scuffle at the blouse sale, where only the women's legs and feet were visible throughout the altercation. In both cases, the fragmentation and isolation of human movements distills the purposelessness of the activities. Like the Toronto street scene, the dance shows a group of strangers who are physically close yet socially alienated. Street culture, shopping, and commercial leisure are all shown to offer a baseless community for Mamie, in contrast to the vital female community which awaits her at the factory.

Also hovering in the fox-trot sequence, but never explicitly named, is the specter of sexuality. Dance halls, along with other sites of commercial culture like the cinema, were frequent targets of upstanding reformers apprehensive about working women's sexual conduct at Toronto's leisure sites. Intimacy among strangers and the physicality of modern social dancing alarmed observers armed with older models of hetero-social interaction. There remained the persistent fear that women might barter sexual favours in exchange for being treated by male patrons whose higher wages granted them more access to commercial venues. ${ }^{19}$

Whereas we might legitimately surmise that Mamie has only just met her lecherous dance partner at the club, Eileen goes out on a pre-arranged date with a familiar beau. The two go canoeing and eat a picnic supper, as their courtship unfolds in a natural setting, rather than in the commercial sphere. Indeed, no signs of urban life are visible in the overhead shots of Grenadier 
Pond and High Park; the couple might well be in the country. Their physical interaction is limited to a playful romp through park fields where no overtly sexual contact takes place. Most significantly, Eileen's entire date transpires before the sun sets, whereas the shadowy walls of the dance hall cast Mamie's activities under the cover of darkness.

Monotonous factory work prompts Mamie's craving for "excitement" during off-hours, the film seems to suggest. Cheap urban amusements that readily cater to these needs offer temptations to working women everywhere, but conscientious employees like Eileen will resist this impulse, engaging in more wholesome pursuits. Although Her Own Fault acknowledges the toll that monotonous factory labour takes on workers, admonishing women to take care of their mental and physical wellbeing, the film seeks to displace Mamie's ailments onto the urban sphere, and ultimately onto a particular model of feminine behaviour practised there. Shopping, dancing, and eating out are to blame, rather than industrialized drudgery.

Unlike Mamie who exploits all of the pleasures modern Toronto has to offer, Eileen calls upon pre-industrial feminine norms to re-cast women's factory work in the guise of traditional femininity. Industrial labour is in fact compatible with traditionally decorous femininity, the film wants to argue; and it can be a healthy and fulfilling occupation for women if performed along Eileen's model. Indeed, the factory itself appears as an ideal community where female workers are given nutritious meals, kindly supervision, and adequate rest periods where they might enjoy fresh air and exercise, or relaxing passtimes like needlework and reading. Such paternalistic attitudes towards female industrial workers were strategies typical of attempts to ensure the continued association of women with the domestic sphere and continuation of patriarchal power structures as women began to shift their chief site of labour from the home to industry, Judy Lown points out. ${ }^{20}$ Mamie, who does not take advantage of the factory's comforts, eventually contracts tuberculosis. In fact, her ill health is not attributed to factory conditions at all; it is her thoroughly cosmopolitan lifestyle which renders her unfit for factory work. Ultimately then, Her Own Fault casts a 
"new woman" - self-supporting and employed in a manufacturing plant - along familiar models of gendered behaviour.

However, persistent associations of Eileen with the preindustrial world belie instances when the film does not obscure the very real industrial structure under which she labours. Frequent references to clocks, watches and time whistles - eight in the course of a 15-minute narrative - suggest the degree to which the women's lives are orchestrated around the needs of industrial production. Shift work dictates when they will rise, when they will rest, when they will eat, and when they will be granted leisure time. Her Own Fault suggests the necessity of internalizing the factory clock, as Eileen does, rather than fighting against it by trying to sleep a little longer in the morning or squeeze some necessary shopping into the lunch hour, as Mamie attempts to do. Individual time must conform to industrial time; bodily habits must be tailored to the work place; the individual must function like a machine. ${ }^{21}$

In a later scene designed to demonstrate the efficiency that results from Eileen's sensible lifestyle, each woman is shown at work trimming rubber shoe soles on identical machines. So rapid is the speed with which Eileen feeds the rubber soles into the cutting mechanism that the shots almost appear to be in fast motion. "Eileen has become the machine," in these images. She is herself mechanized and automated, having conformed to the demands of the factory clock and the rhythms of its machinery. Eileen's mechanized, industrial body is set against Mamie's frenetic, sexualized, overly-adorned urban body. ${ }^{22}$ Visual echoes of frenzied movement resonate across the images associated with Mamie's experience of the urban vortex: street traffic, retail sales and dance halls suggest a level of chaos at odds with the orderliness of Eileen's exemplary productivity.

Recall here the images of the workers exercising on their rest period. Even as the sequence seems designed to further the factory's associations with natural wholesomeness - the women exercise outdoors on a wide lawn out of view of industrial smoke stacks - its very presentation frames the women as mechanized. Shots of them performing synchronized arm and torso movements of questionable merit (under the supervision 


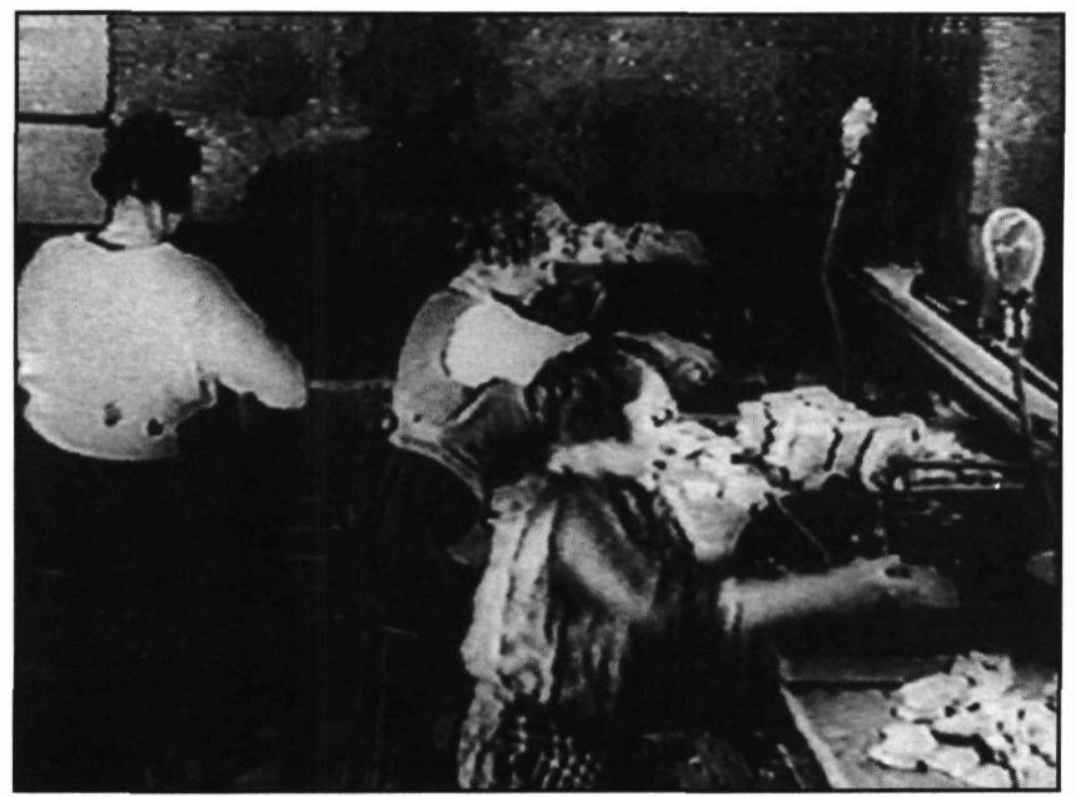

Eileen and Mamie work side-by-side manufacturing shoe soles at the Gutta, Percha and Rubber plant.

of a male instructor) figure the degree to which the factory shapes an industrial female body. The similarity and exactitude of their repetitive motions ostensibly serve to revitalize the workers: "That physical exercise just puts pep into me again," Eileen exclaims. Yet, the exercises only underscore industry's regulation of womanly flesh. Such an image offered the consummate index of modern capital, Siegfried Kracauer would point out only a few years later, for it perfectly embodied the way that the individual body lost all connection to the natural world and became itself an element of industrial rationalization.... ${ }^{23}$

Her Own Fault finally offers a paradoxical message: in its drive for standards of greater efficiency in industrial production, it appeals to a non-industrial context. It attempts to naturalize standards of behaviour beneficial to efficient factory labour by linking them to the natural world and inherent gender characteristics, suggesting that city pleasures, not manufacturing work, corrupt and pervert these natural tendencies. The potentially contradictory spheres of modern industry and womanly nature are rendered 
compatible here through the figure of the efficient worker; the mechanized and regulated female body demanded by modern industry offers an alternative to the sexualized, excessive female body particular to urban culture. Through its structural opposition of two women, Her Own Fault sets the perils of city living against the safety and security offered by up-to-date factory employment. It suggests, contrary to what might be assumed, that modern, cosmopolitan femininity is incompatible with the rigorous demands of factory production, which benefit from the efficiency and rigor inherent in true womanhood.

Besides suggesting her compatibility with older womanly norms, the film engages in a second strategy to legitimize the female industrial worker. It subjects her to a new optical hierarchy governed by the all-encompassing gaze of the province's Division of Industrial Hygiene. By offering advice on everything from grooming to courtship, the Division exercises its jurisdiction over all facets of wage-earners' lives, not just conditions in manufacturing plants where they laboured. Location shooting furthers this effect by showing the Division's cameras - and by extension, its eyes - to be everywhere in Toronto. Taylorist principles of scientific management licensed just such control under the guise of industrial efficiency when they were introduced into Ontario's factories in the late teens, according to Eric Tucker. ${ }^{24}$ The accelerated pace of factory production at this point necessitated strict discipline since the responsibility for output and productivity rested on the shoulders of individual workers. ${ }^{25}$ Ironically, in licensing such surveillance, the Division successfully shifted the responsibility — and blame - for female employees' health onto the shoulders of women themselves, rather than the industrial work place.

Here the intended audience is instrumental, for the Toronto screenings of Her Own Fault help chart the place of educational film-making within this visual topos. If the Division sought to assert the omnipotence of its vision, the films sought to focus the gaze of Toronto's female manufacturing workers. In its use of cinema the Board of Health recognized that, as much as it might want to circumscribe working women's behaviour, such matters could not always be legislated. The suasive forces of 
popular media must be engaged, using tropes which cater to women in their own entertainment milieu. Distribution of $\mathrm{Her}$ Own Fault was coordinated by the Ontario Motion Picture Bureau, as was customary with most films produced by divisions of the provincial government. ${ }^{26}$ Well-versed in the exploitation of motion pictures for educational use, the Bureau " $[\ldots]$ now leads the world in visual education work, ${ }^{27}$ one contemporary writer affirmed. George Patton, head of the Bureau in the 1920s and early 1930s, later claimed " $[\ldots]$ we were the pioneers in Government film producing." 28

The Bureau decided upon an exhibition strategy which specifically targeted Toronto's female labourers, choosing to screen the film at two commercial theatres in the fall of 1921: the Classic Theatre on Gerrard Street East and the Kum-C Theatre on Queen Street West. They were selected as sites which might attract the widest audience of wage-earning women. As the Division of Industrial Hygiene explained, " [...] the bookings have been planned with a view to showing the movie in theatres near where most of the factory girls live. ${ }^{29}$ Both venues were located in squarely working-class neighbourhoods adjacent to billiard parlours on busy commercial thoroughfares, the latter in Parkdale directly around the corner from Gutta, Percha and Rubber where much of the film was shot. ${ }^{30}$ The screenings were promoted in letters sent to over forty different manufacturing plants employing women in downtown Toronto, asking factory owners to alert their employees to the film which the Division of Industrial Hygiene promised would be " $[\ldots]$ interesting to most girl workers. " ${ }^{31}$ Employers were also advised that extra $28 \mathrm{~mm}$ prints and projection equipment could be borrowed for factory-based showings, should they wish to ensure that workers saw the picture. ${ }^{32}$

Despite the Motion Picture Bureau's attempts to have the film seen by as wide an audience as possible, there is nonetheless a particular paradox in the government's use of commercial screening sites. The Bureau had, for the most part, concentrated on non-theatrical screenings in community-based venues, and had encouraged local groups to loan out Bureau films and projectors. ${ }^{33}$ Through such novel exhibition methods Bureau offi- 
cials sought to distinguish the government's filmmaking efforts from motion picture fare offered in commercial theatres, "[...] which entertain without too much mental strain." 34 George Patton had argued that such innovative distribution strategies might "[...] offset the influence of imported pictures with their rather doubtful effect on the Province." ${ }^{35}$ On the contrary, the choice of commercial screening sites like the Classic and the Kum-C invited women to partake of the very urban leisure culture of which Her Own Fault itself is so critical. Cinema is never specifically invoked in the film; yet it would certainly be included by Toronto viewers among the other urban spaces with which Mamie is associated. Why then draw patrons out to Monday and Tuesday evening screenings at theatres along Queen and Gerrard when the film explicitly suggests that women's leisure hours would be better spent outdoors? What was it about movie-going — and particularly film viewing — which the filmmakers felt was especially advantageous from an educational perspective? Was the cinema itself envisioned as an instrument which might induce greater productivity among recalcitrant female workers?

With Her Own Fault the government intervenes in the entertainment sphere, hoping to sway the behaviour of Toronto's working women. It appeals to factory workers whom it most seeks to address not simply by locating screenings in workingclass areas, but by presenting its message on the movie screen, that consummate symbol of urban pleasure in the early twentieth century. Evidence suggests that Gutta, Percha and Rubber employees were indeed eager to see themselves on screen, ${ }^{36}$ an interest fostered by the film's producers. "I hope the girls will be interested in seeing it and will like themselves in the movie," 37 wrote the Division's director. Capitalizing upon this curiosity, the film offers a commanding spectacle of Toronto sights, while focusing a particular view of woman's place within that landscape. Since the film was publicized to the women through their employers, its viewpoint was sanctioned not only by the government, but by the city's manufacturing industry as well. And if screenings were indeed held within factory sites themselves, this view is even further circumscribed. 
Finally, in its efforts to promote hygienic and efficient work practices Her Own Fault inevitably grapples with the vexing figure of the female industrial worker - at once so indicative of modernity and so threatening to femininity. The film poses a novel solution to this conundrum: the efficient factory worker, so necessary to modern industrial production, was the logical outgrowth of an older, pre-industrial mode of femininity and the enemy of urban culture. Yet, by exploiting motion pictures and the field of commercial amusements, even to such a limited degree, the government shows its willingness to exploit new technologies for the purposes of social control. In its attempt to influence Toronto's working-class women, Her Own Fault suggests some of the challenges posed by the female factory worker in the early part of the century, as well as the ways in which cinema might circumscribe her behaviour - and her gaze.

\section{University of California}

\section{NOTES}

1 I am indebted to David Sobel of the Labour History Images Group for bringing Her Own Fault to my attention through his video compilation "The Moving Past." The article could not have been completed without the gracious, helpful staff at the Archives of Ontario, nor the Arts Division at UC-Santa Cruz which provided funds to enable my research. Special thanks are due to my father, Robert Stamp, who guided me through the Archives and Toronto history with expert care.

2 The print of Her Own Fault I viewed is held at the Moving Image and Sound Archives of the National Archives of Canada. The version presented in "The Moving Past" collection is slightly condensed and has an added music track.

3 "Letter from Dr. J.G. Cunningham, Director of the Division of Industrial Hygiene, to F.L. Riggs, Supervisor of the Department of Industrial Relations at Gutta, Percha and Rubber," 27 June 1921 (Division of Industrial Hygiene Correspondence, Provincial Board of Health records, Archives of Ontario).

4 The Division of Industrial Hygiene was formed by the Board of Health in 1919, just two years before the film was made. The Board of Health appears to have made good use of educational films during this period, since its Division of Venereal Disease also contracted with Pathescope Canada to make films and provide projection equipment in the early 1920's (Pathescope correspondence, 1920-26, Provincial Board of Health records, Archives of Ontario).

5 "Letter from Cunningham to various employers," 27 October 1921 (Division of Industrial Hygiene Correspondence, Board of Health records, Archives of Ontario).

6 See Michael J. Piva, The Condition of the Working Class in Toronto, 1900-1921 (Ottawa: University of Ottawa Press, 1979, p. 17); and Marjorie Griffin Cohen, 
Women's Work, Markets and Economic Development in Nineteenth-Century Ontario (Toronto: University of Toronto Press, 1988, p. 119 and 169).

7 For more details, see Wayne Roberts, Honest Womanhood: Feminism, Femininity and Class Consciousness Among Toronto's Working Women, 1893-1914 (Toronto: New Hogtown Press, 1976, p. 7).

8 Excerpts from these articles are reprinted in "A Little Independence: Factory Girls, 1912," in Irving Abella and David Millar (eds.), The Canadian Worker in the Twentieth Century (Toronto: Oxford University Press, 1978, p. 167-179). Also important in this regard was a highly-publicized strike by Toronto switchboard operators against Bell Telephone in 1907 which garnered extensive public sympathy for the conditions under which the women laboured and the mental strain they faced with ever-increasing demands for efficiency. See Joan Sangster, "The 1907 Bell Telephone Strike: Organizing Women Workers," in David J. Bercuson (ed.), Canadian Labour History: Selected Readings (Toronto: Copp Clark Pitman, 1987, p. 43-61).

9 See Alice Klein and Wayne Roberts, "Besieged Innocence: The 'Problem' and Problems of Working Women-Toronto, 1896-1914," in Janice Acton, Penny Goldsmith and Bonnie Shepard (eds.), Women at Work: Ontario, 1850-1930 (Toronto: Canadian Women's Educational Press, 1974, p. 223). See also Wayne Roberts, "'Rocking the Cradle for the World': The New Woman and Maternal Feminism-Toronto, 1877-1914," in Linda Kealey (ed.), A Not Unreasonable Claim: Women and Reform in Canada, 1880-1920 (Toronto: Women's Press, 1979, p. 15-46).

10 For details, see Veronica Strong-Boag, "The Girl of the New Day: Canadian Working Women in the 1920's," Labour / Le Travailleur, vol. 4, $n^{\circ} 4$ (1979) p. 159; and Margaret E. McCallum, "Keeping Women in Their Place: The Minimum Wage in Canada, 1910-1925," Labour / Le Travailleur, $\mathrm{n}^{\circ} 17$ (1986) p. 31. Of course minimum wage legislation did not bring women's salaries in line with men's; women working in Toronto's manufacturing sector earned $43 \%$ less than men in 1921 .

11 See Alice Klein and Wayne Roberts, "Besieged Innocence: The 'Problem' and Problems of Working Women-Toronto, 1896-1914, " in Janice Acton, Penny Goldsmith and Bonnie Shepard (eds.), Women at Work: Ontario, 1850-1930 (Toronto: Canadian Women's Educational Press, 1974, p. 222).

12 See Dawn Sebine, “'To Shield From Temptation': The Business Girl and the City," Urban History Review / Revue d'histoire urbaine, vol. 17, n 3 (1989) p. 203208.

13 Carolyn Strange uses this phrase in the title of her forthcoming book, Toronto's Girl Problem: The Perils and Pleasures of the City, 1880-1930 (Toronto: University of Toronto Press, 1995).

14 "Letter from Cunningham to Miss Livingston, Queen's Hall," 27 October 1921 ; and "Letter from Cunningham to Riggs," 27 October 1921 (Division of Industrial Hygiene Correspondence, Provincial Board of Health records, Archives of Ontario). "Letters from Cunningham to Riggs," 12 May 1921 and 27 June 1921 (Gutta, Percha and Rubber Correspondence, Provincial Board of Health records, Archives of Ontario). It is likely that the film was actually shot and edited by Pathescope Canada under the direction of the Division, as this was customary of the arrangement between the Ontario Motion Picture Bureau and Pathescope between 1917 and 1923. See Peter Morris, Embattled Shadows: A History of Canadian Cinema, 18951939 (Montreal : McGill-Queen's Press, 1978, p. 140). Pathescope approached Cunningham about the possibility of joint filmmaking ventures upon his appointment as Director of the Division, but he appears to have initially rejected this idea, despite interest from the Chief Officer of Health ("Letter from William Redpath, Pathescope Canada, to Cunningham," 17 July 1920; and "Letter from Chief Officer of Health to Pathescope," 20 July, 1920, Pathescope Correspondence, Provincial Board of Health 
records, Archives of Ontario.). The letter to Cunningham bears a hand-written notation "no industrial pictures at moment," signed "J.G.C." Nonetheless, I could find no direct record of Pathescope's involvement with Her Own Fault.

15 Health Confessions of Business Women. By Business Women (Toronto: Division of Industrial Hygiene, Provincial Board of Health, 1923, p. 9-10). The book is a collection of tips on physical and mental health excerpted from letters solicited from the province's working women. It was issued in a printing of 10,000 copies and distributed through companies to their employees (Division of Industrial Hygiene Files, Provincial Board of Health records, Archives of Ontario).

16 For details, see Kathy Peiss, Cheap Amusements: Working Women and Leisure in Turn-of-the-Century - New York (Philadelphia: Temple University Press, 1986, p. 62-67).

17 "In A Dress Factory," The Worker, 12 September 1925.

18 Health Confessions of Business Women, p. 15.

19 On concerns about modern social dancing in the U.S., see Lewis Erenberg, “Everybody's Doin' It : The Pre-World War I Dance Craze, the Castles, and the Modern American Girl," Feminist Studies, vol. 3, nos. 1-2 (1975) p. 155-170. On the practice of treating, see Kathy Peiss, "'Charity Girls' and City Pleasures: Historical Notes on Working-Class Sexuality, " in Peiss and Christina Simmons (eds.), Passion and Power: Sexuality in History (Philadelphia: Temple University Press, 1989, p. 57-69).

20 Judy Lown, " 'Not So Much a Factory, More a Form of Patriarchy': Gender and Class During Industrialization," in Eva Gamarnikow, David H.J. Morgan, June Purvis and Daphne Taylorson (eds.), Gender, Class and Work (London: Heinemann, 1983 , p. $40-41$ and 43 ).

21 The emphasis on the time clock was, of course, precisely what distinguished factory labour from domestic labour. See Margaret Conrad, "'Sundays Always Make Me Think of Home': Time and Place in Canadian Women's History, " in Barbara J. Latham and Roberta J. Pazdroin (eds.), Not Just Pin Money (Victoria: Camosen College, 1984 , p. 7). On the different temporalities wrought by industrialization see Tamara Hareven, Family Time and Industrial Time: The Relationship Between the Family and Work in a New England Industrial Community (Cambridge and New York: Cambridge University Press, 1982, p. 7-8).

22 On the conflicts between Taylorism and sexuality in relation to male workers, see Peter Wollen, "Modern Times: Cinema / Americanism / The Robot," Raiding the Icebox: Reflections on Twentieth-Century Culture (London and New York: Verso, 1993, p. 38-39). John Marshall drew my attention to this essay when he used it in an entirely different context.

23 See Siegfried Kracauer, “The Mass Ornament," New German Critique, n 5 (1975) p. 67-76. I thank Constance Balides for reminding me of the applicability of Kracauer's argument here.

24 Eric Tucker, Administering Danger in the Workplace: The Law and Politics of Occupational Health and Safety Regulation in Ontario, 1850-1914 (Toronto: University of Toronto Press, 1990, p. 78-180). For a discussion of the same principles applied to clerical workers, see Graham Lowe, "Mechanization, Feminization and Managerial Control in the Early Twentieth-Century Canadian Office, " in Craig Heron and Robert Storey (eds.), On the Job: Confronting the Labour Process in Canada (Kingston: McGill-Queen's University Press, 1986, p. 177-209).

25 See Mercedes Steedman, "Skill and Gender in the Canadian Clothing Industry, 1890-1940," in Craig Heron and Robert Storey (eds.), On the Job: Confronting the Labour Process in Canada (Kingston: McGill-Queen's University Press, 1986, p. 160).

26 "Letter from Cunningham to Riggs," 15 September 1921 (Gutta, Percha and Rubber Correspondence, Provincial Board of Health records, Archives of Ontario). For a 
detailed account of the Bureau's filmmaking and distribution activities, see Peter Morris, Embattled Shadows: A History of Canadian Cinema, 1895-1939 (Montréal: McGill-Queen's Press, 1978, p. 137-155). For another informative account of the interest in educational filmmaking in Canada well before the formation of the National Film Board, see Charles R. Acland, "National Dreams, International Encounters: The Formation of Canadian Film Culture in the 1930's," Canadian Journal of Film Studies / Revue canadienne d'études cinematographiques, vol. 3, $\mathrm{n}^{\circ} 1$ (1994) p. 3-26.

27 Canada Weekly, 4 May 1918, p. 13.

28 "Memo from Patton to Mitchell Hepburn, Prime Minister of Ontario and Provincial Treasurer, ” 25 July 1934 (Motion Picture Bureau Correspondence, Hepburn papers, Archives of Ontario).

29 "Letter from Cunningham to Vincent Massey, Massey-Harris Co.," 27 October 1921 (Division of Industrial Hygiene Correspondence, Provincial Board of Health records, Archives of Ontario). The film was screened Monday, October 31 and Tuesday, November 1, 1921.

30 Toronto City Directory, 1921 (Toronto: Might Directories Ltd., 1921). The Classic Theatre was located at 1296 1/2 Gerrard Street East, between Greenwood and Redwood Avenues; the Kum-C Theatre at 1288 Queen Street West, between Noble Street and Brock Avenue. Thanks to Robert Stamp for this information.

31 "Letter from Cunningham to various employers," 27 October 1921 (Division of Industrial Hygiene Correspondence, Provincial Board of Health records, Archives of Ontario). The Division evidently felt the film's message extended to all of Toronto's female work force, and invited the secretary of the the city's YWCA to alert its members: "While the film is written primarily with a view to factory workers, it is thought to be of interest and amusement to most girl workers. Possibly some of your members might like to see it" ("Letter from Cunningham to YWCA," 27 October 1921, Division of Industrial Hygiene Correspondence, Provincial Board of Health records, Archives of Ontario.)

32 "Letter from Cunningham to various employers," 27 October 1921 (Division of Industrial Hygiene Correspondence, Provincial Board of Health records, Archives of Ontario). I found no evidence to suggest whether or not any plant owners took advantage of the Division's offer; nor is there any record of how successful the commercial screenings were. Members of Toronto's reform community were also invited to view the film; but the Bureau hoped to set up an additional screening for these patrons at the more upscale York Theatre, located on Yonge Street in Yorkville, rather than asking them to visit the Classic or the Kum-C. ("Letter from Cunningham to Dr. Ruggles George, Canadian Red Cross," 27 October, 1921, Division of Industrial Hygiene Correspondence, Provincial Board of Health records, Archives of Ontario).

33 "Letter from George Patton to William H. Price, Provincial Treasurer," 30 July 1923 (Motion Picture Bureau Correspondence, Treasury Deparment records, Archives of Ontario). "Letter from Patton to E.C. Drury, Prime Minister of Ontario," 1923 (Ontario Motion Picture Bureau Correspondence, Drury papers, Archives of Ontario).

34 "Letter from H.N. DeWitt, President of Pathescope, to Peter Smith, Provincial Treasurer," 9 November 1921 (Motion Picture Bureau Correspondence, Treasury Department records, Archives of Ontario).

35 "Letter from Patton to Price," 1 November 1924 (Motion Picture Bureau Correspondence, Treasury Department records, Archives of Ontario).

36 "Letter from Riggs to Cunningham," 13 September 1921 (Gutta, Percha and Rubber Correspondence, Provincial Board of Health records, Archives of Ontario).

37 "Letter from Cunningham to Riggs," 27 October 1921 (Division of Industrial Hygiene Correspondence, Provincial Board of Health records, Archives of Ontario). 